\title{
SUBSTANCES CONTROLLING THE GROWTH OF A DIATOM
}

\author{
By H. W. Harvey, Sc.D. \\ Hydrographer at the Plymouth Laboratory
}

The centric diatom Ditylum brightwelli Ehrb. is found in the English Channel during the spring and autumn; in common with many other species it "dies out" during the summer months.

Its life history has been investigated by Gross (1937a) who used for this purpose cultures in sterilized sea water enriched with nitrates, phosphates and soil extract, a culture medium known as "Erdschreiber" (Gross, I937b). The succession of events in its life history may be epitomized as follows. The cells make vegetative divisions for a period of several months, the successive generations of daughter cells becoming narrower. Under some conditions, such as crowding, low temperature and low light-intensity, the contents of a cell may retract into a sphere (resting spore) within the skeleton, and, on change of conditions, this resting spore will grow to refill the parental skeleton. This can happen within a few hours if conditions become suitable soon after the formation of the resting spore. Normal vegetative growth then continues. After many divisions have taken place, with consequent reduction to a certain diameter, the cells become capable of forming auxospores; this takes place under certain conditions of environment, and, if it does not take place, vegetative division continues. This may continue, no auxospores being formed, until the diameter of the cells falls to $10-13 \mu$, when they die. On the other hand, if auxospores are at any time formed, then either one of two things happens. If the environment is unsuitable the auxospores do not develop but perish; if the environmental conditions are suitable the auxospores develop into broad cells with diameters up to $100 \mu$, several times broader than the parent of the auxospores. These broad cells after several months of vegetative division, and reduction in size, again become capable of forming auxospores.

Gross found that formation of auxospores was, inter alia, brought about by transferring the cells from "Erdschreiber" into natural sea water, but that in sea water the conditions were unsuitable for their further development and they perished.

I am indebted to Dr Fabius Gross for a subculture of this diatom in "Erdschreiber". During the late summer and early autumn of 1937 , I found that when it was transferred to natural sea water enriched with nitrates, phosphates, silicates and iron, most of the cells formed auxospores which did not develop and the remaining cells did not make vegetative divisions. The inability of auxospores to develop in natural sea water collected in the summer was not solely due to lack of phosphates, nitrates, silicates and iron. If a small quantity 
of soil extract was added to the enriched natural sea water, an inoculum of actively dividing diatoms would continue to grow vigorously by vegetative division. This happened repeatedly. It was found that the soil extract could be replaced by an extract of Fucus or of Ulva which had been allowed to undergo bacterial breakdown and had been separated from the bacteria and colloids by dialysis.

Sea water collected in late October 1937 behaved quite differently from sea water collected during the summer. When this was sterilized and enriched to the same extent with phosphates, nitrates and iron, the diatoms would grow in it without any further addition of soil or algal extract. This was found to happen with samples of water collected from time to time throughout the winter of 1937 and spring 1938.

Meanwhile a second strain of this species was grown from a single cell isolated from the sea in April 1938. It made considerable growth in water collected during the spring and during the previous winter, enriched with nitrates, phosphates and iron. In water collected during July 1938, similarly enriched, both strains formed auxospores which did not develop.

The inference drawn from these observations on growth in natural sea water is that these two particular strains of Ditylum brightwelli require for continued growth, not only a supply of available nitrogen, phosphate and iron, but, in addition, some other accessory substance or substances, whose concentration in offshore sea water was less than the necessary limit during the summer of I 937 and 1938. In the autumn of 1937 either the accessories were re-formed or a body of water containing the accessories had moved into the area. This "fertile water" either lost its fertility or was gradually replaced during the early summer of 1938 . Samples of offshore water collected during the autumn and winter of 1938 behaved in the same way as water collected during the summer-there was no return of "fertile water".

Accessory substances are not necessary for the growth of all species of marine diatoms. Indeed, the pennate diatom Nitzschia closterium forma minutissima has been found capable of continued growth in synthetic media free from organic matter (Peach \& Drummond, 1924). Originally isolated by Allen \& Nelson (I910) it has had widespread use in many laboratories, and is remarkable for the ease with which it may be kept in culture in natural sea water enriched with nitrate, phosphate and iron. However, it has been repeatedly observed that if soil extract or an algal extract is added to the enriched sea water, the rate of growth is markedly increased. This happens even if the water is heavily loaded with both iron and silicate in addition to nitrate and phosphate (Harvey, 1933). With this Nitzschia, the accessory substances do not act as nutrients necessary for growth, as they do for the two strains of Ditylum, but they act as a growth stimulant.

Throughout this investigation, the natural and artificial sea waters used in the experiments were enriched with $30 \mathrm{mg}$. nitrate $\mathrm{N}, 3 \mathrm{mg}$. phosphate $\mathrm{P}$ and $c a$. $0 . \mathrm{I} \mathrm{mg}$. $\mathrm{Fe}$ as ferric ammonium citrate per litre. The quantities of nitrogen and phosphorus 
added are in similar proportion to each other as they are in diatoms, are sufficient for the growth of several thousand Ditylum cells per c.c., and are in the region of optimum concentration. The amount of iron added was considered to be in gross excess of requirements, provided it remained available (Harvey, I937).

It was thought that silicate occurring in the various extracts which were added in the experiments might have affected growth, but experiments did not show this to be so, sufficient being derived from the glass vessels. Later, when a means of producing very luxuriant growth had been discovered, it was found necessary to add silica if more than a few thousand cells per c.c. were to develop in the culture medium.

The method used in carrying out the biological tests was to transfer Ditylum cells from an actively dividing culture to the medium used for the control, collect them by centrifuging or allowing to sediment, again suspend them in the medium and sediment, then suspend them once more in the medium and use equal volumes of this to inoculate equal volumes of the control and experimental media. The cells were then kept, either at room temperature or at $13^{\circ} \mathrm{C}$., where they received nearly equal illumination, but no direct sunlight. When relatively small differences in growth rate or final "crop" were to be observed, the glass vessels were kept on a slowly rotating table, so that they averaged equal illumination, and in order that the "lens effect" in the cylindrical vessels should be eliminated.

\section{Growth in Artificial Sea Water}

Allen (I9I4) found that the diatom Thalassiosira gravida would make no growth in an artificial sea water made with glass-distilled water and pure chemicals, providing chloride, sulphate, sodium, potassium, magnesium and calcium in the proportions in which they occur in sea water, with the hydrogenion concentration adjusted with bicarbonate and enriched with phosphate, nitrate and iron. The further addition of bromide and iodide was without effect, but, if a very small proportion of natural sea water or of a boiling water extract of Ulva was added, then a rich growth of this diatom took place.

From a long series of experiments he concluded that natural sea water contained a substance or substances of organic nature which was necessary for the growth of this diatom.

Peach \& Drummond (1924) investigated the growth of Nitzschia closterium forma minutissima in similar artificial sea water and found that this species would grow without any addition of accessory substances. This species appears unique among marine diatoms for the adverse conditions, fatal to other species, which it will withstand. Allen (private communication) repeated Peach \& Drummond's experiments with similar result, but observed that better (more rapid) growth was brought about by the addition of a small proportion of natural sea water or of Ulva extract. It has been repeatedly observed by the writer that the addition of such extracts hastens the growth of Nitzschia, even in sea water heavily enriched with inorganic nutrients.

A similar "artificial sea water" was made and enriched with nitrate, phosphate and iron. Neither strain of Ditylum would grow in it. With the addition of $5 \%$ of natural winter sea water a rather poor growth resulted, while with the addition of soil or of algal extracts a considerable growth took place. The 
very small additions, which had been found by Allen to suffice for the growth of Thalassiosira, ${ }^{\star}$ were insufficient for the growth of Ditylum.

It is thought that the Nitzschia species can itself make the organic accessories which it needs for continued growth, that is to say that the accessories are of the nature of phytohormones. In support of this hypothesis are the observations that addition of "accessories" to the water causes more rapid growth, and an observation that it grows more rapidly in water in which the species has been growing previously (Harvey, 1933).

Experiments on the growth of Ditylum soon showed that the active principles which are present in soil extract and in algal extracts could be separated into two groups. The one, which will be termed group "A" accessories, was readily adsorbed on carbon and was insoluble in aqueous butyl alcohol. The other, group " $\mathrm{N}$ " accessories, was not adsorbed on carbon and was soluble in aqueous butyl alcohol.

The addition to "artificial sea water" of "A" alone, or of cystine which has been found capable of replacing it (p. 504), would not allow a vigorous growth of Ditylum. There was some other factor " $\mathrm{N}$ " in soil and algal extracts and in natural sea water which was not adsorbed on carbon and which was necessary in addition to " $\mathrm{A}$ " for a vigorous growth and considerable crop of Ditylum.

The action of the group " $\mathrm{N}$ " accessories is complementary to the action of group "A". The increase in growth of Ditylum brought about by the addition of " $A$ " and " $N$ " together exceeds the sum of the increases brought about by the addition of each singly; the effect of " $\mathrm{A}$ " is enhanced by the presence of " $\mathrm{N}$ " and vice versa.

The following experiments are typical.

Ditylum cells were washed in "artificial sea water", and equal volumes of media were inoculated with equal volumes of the Ditylum suspension on February I4. On February 28 counts were made with the following result:

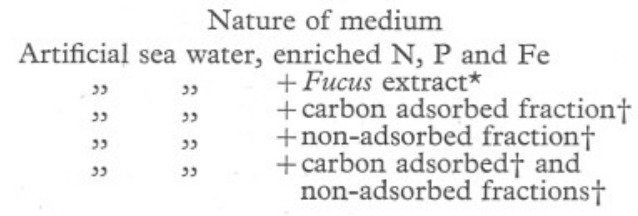

Cells per c.c.

circa 2200

678

517

I8I8

The Fucus extract had been broken down by bacteria and dialysed. The quantity * added per litre of artificial sea water was derived from I4 g. of Fucus. After fractionating by adsorption on carbon, the quantity of either fraction $\dagger$ added per litre of water was derived from $20 \mathrm{~g}$. of Fucus.

The increase of cells per c.c. was

498 due to the addition of the adsorbed fraction,

I3OI due to the addition of the adsorbed fraction in the presence of the non-adsorbed fraction.

* The extract from $0.5 \mathrm{~g}$. of Ulva added to I 1. of "artificial sea water" was sufficient for the growth of Thalassiosira. 
In another experiment, carried out in the same manner, the following counts after 8 days' growth (March I5-23) were made:

Nature of medium

Artificial sea water enriched $\mathrm{N}, \mathrm{P}$ and $\mathrm{Fe}$

Cells per c.c.

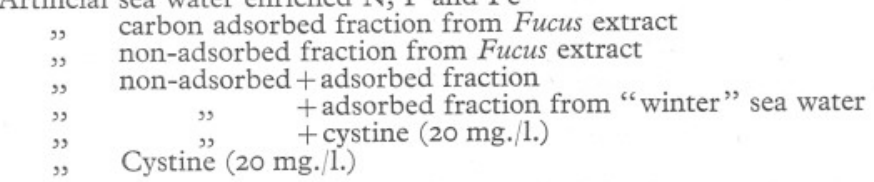

The increase in number of cells per c.c. was

260 due to the addition of cystine,

I 375 due to the addition of cystine in the presence of the non-adsorbed fraction,

75 due to the addition of the adsorbed fraction,

555 due to the addition of the adsorbed fraction in the presence of the non-adsorbed fraction.

The complementary effect of the two fractions was even more marked in several other experiments. Thus in one experiment the increase in number of cells per c.c. was Io9 due to addition of cystine alone,

1636 due to addition of cystine alone in presence of non-adsorbed fraction from Fucus.

\section{ON THE NATURE OF "A" ACCESSORIES}

Soil extract has been extensively used as a source of "growth stimulant" or "accessory nutrients" in rearing various marine larvae, Protozoa and algae in vitro. It appears that its effect is not limited to very simple organisms. Pringsheim, who has reviewed the literature (1936), has found from his own experiments on flagellates that the active principle was adsorbed on carbon and was insoluble in ether and in alcohol.

From experiments on the growth of Ditylum in enriched sea water collected during the summer of 1937 it was found that an active principle was adsorbed on carbon from either neutral or acid soil and algal extracts. It could be eluted from the carbon by a solution of ammonia or by boiling with acid alcohol and subsequent treatment with alkali. The addition of this eluted preparation to enriched "summer" sea water rendered it capable of growing a considerable crop of Ditylum.

The most convenient method was to boil soil extract, or algal extracts which had undergone bacterial decomposition, or natural sea water, with "decolorizing carbon" which had previously been heated to a dull red and washed with hot hydrochloric acid. The carbon, after washing with water, was then eluted at least twice with a hot $2 \frac{1}{2} \%$ solution of ammonia in $60 \%$ acetone. The solution was evaporated, dissolved in dilute sodium bicarbonate, dried to get rid of ammonium, and then neutralized.

It was also found that on heating under a reflux with acid alcohol, the active "A" principle passed into solution, presumably as an ester or internal anhydride. On drying and heating with sodium bicarbonate to saponify, active preparations were obtained. The active principle, as Pringsheim had found, was not dissolved in boiling alcohol or ether from either acid, alkaline or neutral residues. 
The "ester" after freeing from acid alcohol was sometimes insoluble and sometimes partly soluble in ether. Ether solutions, which were active after saponification, were obtained in some instances, but not always.

It is concluded from these experiments that part at least of the "A" activity is due to an organic acid. The difficulty of obtaining an ether solution of its "ester" suggests that it has either basic properties or many hydroxyl groups.

The concentration of the active principle from extracts of algae presented difficulties, mostly owing to its being readily adsorbed on the impurities when they were precipitated. Continuous extraction with warm aqueous butyl alcohol proved useful, as this removed many of the amino acids and left the "A". To assess the losses which occurred during each step of a process was also impracticable during the earlier steps, since the addition of a crude extract to sea water led to a considerable development of bacteria which sometimes, but not always, interfered materially with the growth of the diatoms.

The proliferation of bacteria in a diatom culture is usual when the diatoms start to die and their soluble organic constituents diffuse into the water, providing food for the bacteria. It has been frequently considered that the growth of bacteria kills the diatoms, and this undoubtedly happens in some cases. In other cases, the growth of bacteria appears to be the effect rather than the cause of the diatoms' death. In many instances it has been noticed that the addition of an algal extract has led to the culture becoming cloudy with bacteria, but, in spite of this, the addition has brought about increased growth of the diatom.

If the addition of a preparation led to little or no increased growth there was always the possibility that, although active, its effect had been offset by the growth of bacteria. Moreover, a falling off in activity has been noticed in many of the preparations, some of which became entirely inactive in the course of a few weeks. The growth of bacteria appears to have little or no destructive effect on active preparations, but the growth of moulds destroys the active principle.

With regard to the quantities of these algal extracts which were necessary to show a well-marked effect on the growth of Ditylum, it was found that the extract from $5 \mathrm{~g}$. of Fucus, made by boiling with $\mathrm{N} / \mathrm{ro} \mathrm{HCl}$, drying, washing with alcohol and ether and neutralizing, was about the minimum necessary for addition to I 1 . of sterilized "summer" sea water.

Several organic acids, or chemical groups which occur in these acids, are known, which affect the growth of plants and Protozoa, in some cases being necessary for the growth of a particular species in artificial media. Hammett (1930) has found that a number of compounds containing divalent sulphur affect the growth of plants and Paramoecium; of these substances cystine is typical.

The effect of adding $l$-cystine to water collected during the summer of I937 was tried and found to give positive results. It brought about a moderate growth provided it was added in relatively large quantity, Io mg./1. or more. At concentrations of I mg./1. or less it had only a slight effect. Later experiments with natural sea waters suggested that $0.5 \mathrm{mg}$./1., or possibly rather less, may materially increase the growth of this diatom, provided iron, manganese, silica and naturally occurring organic compounds were present in sufficiency. 
It is thought that " $\mathrm{A}$ " occurring naturally in sea water is unlikely to be cystine only, although this occurs abundantly in marine algae (Mazur \& Clark, I938), and is readily adsorbed on carbon under the conditions employed in this investigation. In the first place the total organic matter in sea water probably does not exceed $5 \mathrm{mg}$. 1 . (Keys, Christiensen \& Krogh, I935), and in the second place an active preparation has been obtained by adsorption on carbon from an algal extract which had been deaminated.

Cystine, however, has proved most valuable throughout these experiments as a substitute for group $A$, and, incidentally, for keeping stock cultures healthy and actively dividing.

Glutathione which contains the same $-\mathrm{S} . \mathrm{CH}_{2} \cdot \mathrm{CH}\left(\mathrm{NH}_{2}\right) \mathrm{COOH}$ group and methionine $\mathrm{CH}_{3}$. S. $\mathrm{CH}_{2} \cdot \mathrm{CH}\left(\mathrm{NH}_{2}\right) \mathrm{COOH}$ were found to act in the same way as cystine.

It is known that the addition of aneurin (vitamin $B_{1}$ ) is effective in promoting the growth of various moulds, bacteria and the embryos of higher plants in synthetic media, and that in some cases its immediate degradation products are equally effective.

The effect of adding aneurin chloride in place of " $\mathrm{A}$ " accessories was then tried. It was usually found to be active in concentrations down to about $0.25 \mathrm{mg} . / 1$.

Growth of Ditylum after Io days (May 13-24) in artificial sea water containing nitrates, phosphates, iron, "additional salts" and $\mathrm{N}_{R}$ (see p. 507):

With no further addition
With $\mathrm{r} .25 \mathrm{mg}$./1. aneurin chloride
With 0.25
With 0.05

Cells per c.c.

526

II 70

I000

700

Again, the concentration of aneurin is much higher than could be expected to have occurred in sea water during the winter of 1938 , and, moreover, in several instances it has been found to have no effect.

Another pure substance, the supply of which affects the growths of higher plants, yeasts and moulds, is biotin, the bios II of yeast, a basic sulphur containing acid, isolated from the yolk of eggs by Kögl \& Tonnis (I936) after a long series of fractionations which included adsorption on carbon and "esterification". Starting from an extract of egg yolks and following the earlier stages of fractionation (precipitation of impurities with $50 \%$ acetone, $85 \%$ alcohol, normal and basic lead acetate, followed by adsorption on carbon), a crude preparation was made of which the biotin content was calculated from Kögl \& Tonnis's data. This was found to be active, replacing " $\mathrm{A}$ ”, in experiments with Ditylum in artificial sea water. Provided that its activity was due entirely to its biotin content and not to impurities, the concentration necessary was of the order of 0.005-0.0I mg. biotin per litre.

This is more nearly approaching a concentration which might conceivably 
occur in the sea; moreover, the active principle in algal extracts behaves like biotin in so far as its properties have been observed.

It has been found by Kögl \& Haagen-Smit (I936) that aneurin and biotin together had more effect on the growth of pea embryos in synthetic media than the effect of each singly. Kögl \& Fries (I937) have found that some moulds require aneurin while others need biotin also for growth in synthetic media. With this in view, the effect of a mixture of $0.002 \mathrm{mg}$. aneurin and $0.0005 \mathrm{mg}$. "biotin" per litre was tried in place of "A", but found inactive towards the growth of Ditylum at these dilutions.

These experiments show that "A" activity is not limited to a single compound, and lend support to the idea that " $\mathrm{A}$ " occurring naturally in sea water may be a group of substances. It is perhaps significant that both aneurin, biotin, cystine and the related compounds glutathione and methionene all contain divalent sulphur.

\section{ON "N" ACCESSORIES OCCURRING IN Algal Extracts}

The crude preparations of " $\mathrm{N}$ ", left after adsorbing the " $\mathrm{A}$ " content on carbon from algal or soil extracts, would naturally contain traces of various elements which may be beneficent or necessary for the growth of Ditylum and may be absent in this artificial sea water. Boron, which is present to the extent of some $5 \mathrm{mg}$. $/ 1$., is an instance, none having been included in the artificial sea water.

It was found that the addition of borate did cause improved growth of Ditylum, and the further addition, to the extent of $0.025 \mathrm{mg}$. $/ 1$., of copper, manganous, arsenic as arsenate, cobalt and zinc salts caused an even slightly better growth. It is seen from the following experiment that these "additional salts" did not take the place of "N".

Equal quantities of Ditylum were used to inseminate equal volumes of artificial sea water enriched with nitrates, phosphates and iron. After 7 days' growth (March 25April I) the following populations were found:

$\begin{array}{cc}\text { In artificial sea water } \\ , y & , \\ y & ,\end{array}$

$$
\begin{aligned}
& \text { + cystine } 20 \text { mg. } 1 \text {. } \\
& + \text { cystine + "additional salts" } \\
& \text { + cystine + non-adsorbed fraction } \\
& \text { of Fucus extract }
\end{aligned}
$$

Cells per c.c.

$$
\begin{array}{r}
46 \\
160 \\
315 \\
\text { I } 190
\end{array}
$$

The further addition of iodate, iodide and bromide was without apparent effect.

Experiments with non-adsorbed fractions of algal extracts showed that the active "N" principle was insoluble in ethyl and butyl alcohol, in acetone and in ether, but soluble in warm aqueous butyl alcohol. It was destroyed by ashing and by boiling with acid alcohol, suggesting that it is an organic compound.

It was found that treatment with normal aqueous hydrochloric acid at boiling-point, with subsequent evaporation and neutralization, made the fraction more active. It is concluded that part of the " $\mathrm{N}$ " occurred in com- 
bination in the algal extract and was set free by this treatment. Similar treatment with sodium bicarbonate had little effect on the activity. The extent to which such activation is brought about by evaporating with normal hydrochloric acid is shown in the following experiment:

Equal quantities of Ditylum were added to equal volumes of artificial sea water enriched with nitrate, phosphate, iron, "additional elements" and cystine. After 7 and I4 days' growth the number of cells were counted (April I2-26):

\section{No addition \\ + non-adsorbed fractions of Fucus extract + same treated hydrochloric acid}

$\begin{array}{cc}\text { After } 7 \text { days } & \text { After I4 days } \\ 86 & 95 \\ 230 & 1875 \\ 267 & 4060\end{array}$

Fractionation of Fucus extracts after the "A" had been adsorbed on carbon was attempted. It was found that the active "N" principle was not precipitated by normal lead acetate, but was partly precipitated by basic lead acetate, from which it could be regenerated by the action of sulphuretted hydrogen.

The fraction so obtained, which will be termed " $\mathrm{N}_{R}$ " when added to artificial sea water together with "A" or cystine or aneurin chloride or crude "biotin", allowed a vigorous growth of Ditylum to take place with the production of some thousand cells per c.c.

Several preparations of " $\mathrm{N}_{R}$ " have been made from algal extracts which were first treated with normal lead acetate, filtered, and then made alkaline with ammonia; the washed precipitate was suspended in water made acid with $\mathrm{HCl}$, treated with sulphuretted hydrogen for $24 \mathrm{hr}$. or longer, boiled and filtered clear from lead sulphide. After boiling with carbon the solution was evaporated, dissolved in dilute sodium bicarbonate and again dried to get rid of ammonium. After neutralization, these preparations showed an activity complementary to accessory "A" or cystine.

The growth which occurred in five illustrative experiments is shown in the following table. The experiments were made in the manner already described:

Exp. (April r2-I9).

Artificial sea water

Nature of medium

Cells per c.c.

After 7 days

$$
\begin{aligned}
& \text { " } \quad \text { +adsorbed fraction from Ulva } \\
& , \quad \text { + non-adsorbed fraction from Fucus } \\
& \text { + adsorbed + non-adsorbed fractions } \\
& +\mathrm{N}_{R} \\
& +\mathrm{N}_{R}+\text { adsorbed fraction + "additional salts" }
\end{aligned}
$$

$$
\begin{array}{r}
27 \\
25 \\
73 \\
206 \\
34 \\
150
\end{array}
$$

Exp. (April 25-May 5).

Artificial sea water containing "additional salts"

$$
\begin{aligned}
& +\mathrm{N}_{R} \\
& + \text { aneurin chloride } 0.25 \mathrm{mg} . / 1 \text {. } \\
& +\mathrm{N}_{R}+\text { aneurin chloride } \\
& + \text { cystine } 20 \mathrm{mg} . / 1 .
\end{aligned}
$$$$
+ \text { cystine }+\mathrm{N}_{R}
$$

*Natural sea water" (sample a) collected April 1938

$\star$,$\quad$ (sample $b$ ) collected January I938

After 7 days

After ro days

29
42
29
250
119
590
461
220

circa 29

74

circa 29

320
156

circa 590

860

350

\footnotetext{
* Enriched with nitrate, phosphate and iron to the same degree as the artificial sea water.
} 


\section{Nature of medium}

Exp. (May 13-23).

Artificial sea water containing "additional salts"

$$
\begin{aligned}
& +\mathrm{N}_{R} \\
& + \text { cystine } 20 \mathrm{mg} . / 1 \\
& +\mathrm{N}_{R}+\text { cystine }
\end{aligned}
$$

Exp. (March 29-April 4).

Artificial sea water

$$
\begin{aligned}
& \text { }, \quad+\mathrm{N}_{R} \\
& \text {, }, \quad \text { +cystine } 20 \mathrm{mg} \text {. } / 1 \text {. } \\
& \text {, }, \quad \text { + cystine }+\mathrm{N}_{R} \\
& \text { " }, \quad+\text { non-adsorbed fraction from Fucus } \\
& \text { " + non-adsorbed fraction + cystine }
\end{aligned}
$$

Exp. (April 30-May 9).

Artificial sea water with "additional salts" and with $\mathrm{N}_{R}$

$$
\begin{aligned}
& \text { " } \quad \text { + cystine Io mg./1. } \\
& \text { " " + biotin } 0.01 \mathrm{mg} \text {./1. containing "impurities" } \\
& \text { * } " \quad \text { + biotin } 0.001 \mathrm{mg} .1 \text {. }
\end{aligned}
$$

Cells per c.c.

After ro days

I84

254

456

I 20

After 6 days

$$
\begin{array}{r}
42 \\
372 \\
277 \\
122 \\
561
\end{array}
$$

* Enriched with nitrate, phosphate and iron to the same degree as the artificial sea water.

It was particularly noticeable that, in order to obtain a good growth of Ditylum in artificial sea water, preparations of "A" and " $\mathrm{N}$ " derived from relatively large quantities of algae were required. It is assumed that losses in preparation were great. The additions of an extract of Fucus, which had undergone bacterial breakdown and had not been subjected to further fractionation, allowed a considerable growth of Ditylum when added in much smaller quantity.

It was observed that preparations of " $\mathrm{A}$ " and " $\mathrm{N}$ " were liable to lose activity on keeping. Sometimes they lost their activity within a few weeks; in one instance this happened with a preparation which had been kept with its activity apparently unimpaired for several months previously.

The growth of Ditylum in artificial sea water with added accessories was rarely so good as in a natural, freshly collected "I937-8 winter" sea water. No general conclusion can be drawn, but it does seem likely that the "A" and " $\mathrm{N}$ " in "fertile" sea water are both groups of substances, and that the preparations used in these experiments did not contain all the accessories needed for optimum growth, although they sufficed for a moderate growth owing perhaps to their having been added in large quantity.

These experiments with artificial sea water have indicated that " $\mathrm{A}$ " accessories-replaceable by the $-\mathrm{S}-\mathrm{CH}_{2} \mathrm{CH}(\mathrm{NH})_{2} \mathrm{COOH}$ group-are necessary for the growth of Ditylum. They even suggest that, for this species and for the media employed, "A" accessories act as a limiting factor in the sense used by Blackman. An alternative view, perhaps better justified by subsequent experiments is that there are a number of accessory or growth promoting substances, including the potent $\mathrm{S}-\mathrm{CH}_{2}-\mathrm{CH}(\mathrm{NH})_{2} \mathrm{COOH}$ group, an increase in any one of which tends to bring about increased growth, and will do so if other, interacting, substances are present. 


\section{Concerning the "Physiological State" of the Inoculum}

When inoculating a series of samples of media to test their relative capacity to support a growth of Ditylum, actively dividing cells from a stock culture were always used. Excellent agreement between their growth in duplicate samples was obtained. On repeating the experiments, using actively dividing cells, usually from a subculture of the stock previously used, similar results were usually obtained. In the repeat experiments conditions for growth were not identical with the conditions in the previous experiment. In particular, the illumination differed during the course of the two experiments. Occasionally it happened that the repeat experiments did not show the beneficial effects of an added accessory which were shown in the previous experiment; this happened several times when using vitamin $\mathrm{B}_{1}$ in place of " $\mathrm{A}$ ".

It was apparent that the response of the inoculum to the conditions of the experiment-light, quantities and nature of the " $\mathrm{A}$ " and " $\mathrm{N}$ " accessories added, temperature, etc.--depended to some extent on the "physiological state" of the Ditylum cells in the inoculum. For instance, it was noticed that insemination with very rapidly dividing cells, such as occurred in a stock culture during bright weather at $13^{\circ}$, tended to give a greater crop than an insemination with less rapidly dividing cells, as from a stock culture at $8^{\circ}$, or one at $13^{\circ}$ in which a considerable growth had already taken place, the growth rate had started to slow down and the cells had become darker in colour than during the earlier and more rapidly growing phase.

The optimum conditions of light, for growth of a diatom, appear to depend to a large extent upon the conditions under which the diatom has lived previously, that is upon its "physiological state". This is illustrated in the following experiment:

A culture of Biddulphia mobiliensis was divided into two parts. One was then grown in a north window in relatively dim December light. The other portion was grown near an electric bulb immersed in a bowl of running water; it received continuous light of some 18,000 lux. The illumination was measured with a photometer which Dr W. R. G. Atkins had very kindly rated for me in diffuse daylight of varying intensities against a similar photometer which had been standardized in artificial mean noon sunlight. At the end of a week, subcultures of each of these cultures were made in sea water enriched to the same extent. Each subculture was divided into ten glass vessels. They were immersed in two water-baths, one kept at $13^{\circ} \mathrm{C}$., the other at $18^{\circ} \mathrm{C}$., at different distances from an electric bulb which was immersed in each bath. The light which each vessel of culture received was measured. After $72 \mathrm{hr}$. continuous light, a sample from each vessel was taken out, poisoned, and the diatoms per c.c. counted. From these counts the percentage increase in number of cells which had taken place during the $72 \mathrm{hr}$. was calculated:

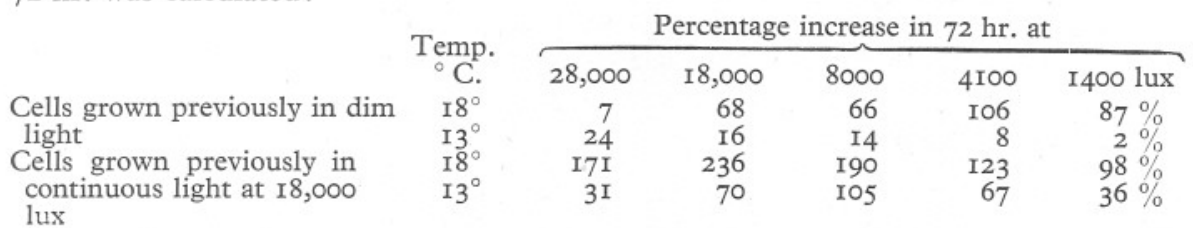


This experiment is interpreted as showing that the optimum light intensity varies both with the "physiological state" of the diatom and with the temperature, and, furthermore, that the effect of temperature on growth rate varies with both the light intensity and the physiological state of the diatom.

In view of this experiment it is not surprising that similar results were not invariably obtained in experiments carried out at different illuminations and with inseminations of Ditylum which had lived under different conditions. In these experiments the nature and quantity of the added substances were controlled, but the other two variables-" physiological state" of the inoculum and light intensity-were not controlled. Moreover, it is possible that differences in the "physiological state" of the diatom are bound up with differences in its capacity to synthesize factors which it requires for vigorous growth, or to utilize partly preformed substances in the external medium for the final production of its requirements. Thus it has been found for some species of bacteria, that they lose their power of growing in synthetic media if they have been cultured persistently in a medium containing a preformed "factor".

Some observations made in particularly dull weather during the winter of I938 suggest that, for slow growth, the requirements of Ditylum are different from its requirements for rapid growth during bright weather. It was noticed that the response to addition of organic compounds having " $\mathrm{N}$ " activity was less than during bright weather.

\section{Growth in Natural Sea Water}

When actively growing cells of Ditylum were transferred to natural sea water, collected several miles offshore at intervals during the summer of 1937 and enriched with nitrate phosphate and iron citrate, they ceased making vegetative divisions and many of the cells formed auxospores which did not develop. In water collected in late October 1937, enriched in the same way, the cells continued vegetative growth, and this ability of the water to support vegetative growth was found in samples collected at intervals during the winter and following spring, mostly at a distance of 20 miles offshore. By June 1938 there was a falling off in the growth which the water would support after enrichment.

Water collected from the surface on July I2, filtered and enriched, allowed only a few divisions to take place. Water collected on July 24 from $5, I_{5}$ and $50 \mathrm{~m}$. at a position 20 miles offshore would allow no more than some two divisions to take place before either auxospores developed or the cells died.

On July 28 water samples collected on July I2 and 24 were filtered, sterilized and enriched with $\mathrm{N}, \mathrm{P}$ and $\mathrm{Fe}$ in identical manner, they were inseminated with $2 \mathrm{I}$ cells of Ditylum (strain T) per c.c. On August 2 counts were made:

$\begin{array}{ccc} & \text { Vegetative cells } & \text { Auxospores } \\ \text { Surface water of July I2 } & 268 & 55 \text { per c.c. } \\ \text { From I5 m. July } 24 & 4 & 65 \\ y & 5 \% & \text { Similar to I5 m. } \\ & 50 \% & \text { Similar to I5 m. }\end{array}$


On July 29 a similar experiment was made using strain G Ditylum of which I9 cells per c.c. were added. On August 3 counts were made:

Surface water of July I2 From $15 \mathrm{~m}$. July 24
Vegetative cells
I06
I0
Auxospores 38 per c.c. 30

These waters collected in July 1938 behaved towards Ditylum in the same way as waters collected at intervals during the summer of the previous year.

The July waters responded to the addition of cystine alone, allowing a healthy growth and moderate crop of Ditylum, with the exception of water from I $5 \mathrm{~m}$. collected on July 24 . This sample only gave a poor growth with the addition of cystine, but with the further addition of an Ulva preparation containing " $\mathrm{N}$ " it behaved as the others did with the addition of cystine only, giving a healthy and vigorous growth.

In the course of experiments on the growth of Thalassiosira gravida in artificial sea water Allen (19I4) had observed that the addition of a small percentage of sea water from the aquarium tanks was more effective in promoting a vigorous growth of the diatom than similar additions of water collected from the sea. "The tanks of the Plymouth Aquarium are worked on a closed system of circulation, the same sea water being circulated over and over again, so that the principal difference between the water taken from them and that obtained from outside consists in the greater abundance in the tank water of organic compounds, which result from the metabolism of living organisms." He further observed that "on the whole, samples of water taken from Plymouth Sound give better growths than are obtained from samples from the English Channel in the neighbourhood of the Eddystone". The water in Plymouth Sound contains more organic matter in solution than water from the open sea. It receives a continuous discharge of sewage in addition to land drainage.

On August I2 samples of water were collected from

(a) The entrance to Plymouth Sound, off Penlee Point, at half ebb from near the surface.

(b) A position 6 miles offshore from near the surface.

(c) A position 20 miles offshore from near the surface.

(d) A position 20 miles offshore from $5 \mathrm{~m}$. depth.

(e) A position 20 miles offshore from $50 \mathrm{~m}$. depth.

Each sample was filtered, heated, and enriched with nitrate, phosphate and iron on August I 7 in identical manner and inseminated with the same quantity of Ditylum cells washed with and suspended in artificial sea water. The cells were of various sizes, some narrow and long, others broad and short which had developed from auxospores about a week previously; the initial population of added cells was 28 per c.c. Two days later auxospores had developed in the waters from 5 and $50 \mathrm{~m}$. depths. 
On August 22 counts of the living cells were made:

In water from surface, 20 miles offshore

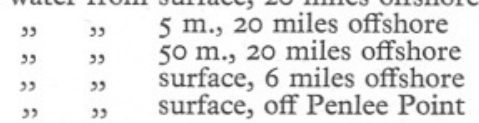

Cells per c.c., including auxospores 284 , many auxospores 53 , nearly all auxospores I38, nearly all auxospores 238 , many auxospores I800, no auxospores

As part of this experiment the same series was also grown, with the addition of Io mg./1. of cystine. The same quantities of the same Ditylum were used to inseminate the waters. The same light conditions and temperature prevailed, the cultures being kept on a revolving table. On August 22 counts were made:

In water from surface, 20 miles offshore + cystine

$\begin{array}{lll}" & \Rightarrow & 5 \mathrm{~m} ., 20 \mathrm{miles} \text { offshore + cystine } \\ " & \Rightarrow & 50 \mathrm{~m} ., 20 \text { miles offshore + cystine } \\ " & \Rightarrow & \text { Surface, 6 miles offshore + cystine } \\ " & \text { Surface, off Penlee Point + cystine }\end{array}$

Cells per c.c. including auxospores 2400, no auxospores 437, some auxospores 284 , nearly all auxospores circa 2400, no auxospores 2500, no auxospores

Similar results were obtained in further experiments. With the onset of winter of 1938 there was no change in the inability of offshore water to support a vegetative growth of Ditylum. Waters collected on November 4 and 29 I938 and January 2 I939 proved singularly infertile after enrichment with nitrate, phosphate and iron.

Meanwhile a series of experiments had shown that lack of manganese in natural sea waters could render them infertile for Ditylum. The addition of $20 \mathrm{mg}$. Mn per cubic metre to the November 4 and 29 waters in both cases made them capable of supporting a considerable, yet limited, growth of Ditylum, some 2000 cells per c.c. being produced.

Offshore sea water collected on November 29 I938 and on January 2 I939 were filtered, heated to $90^{\circ} \mathrm{C}$. and enriched with $\mathrm{N}, \mathrm{P}$ and $\mathrm{Fe}$ in identical manner on January 6, when both were inseminated with 26 cells of Ditylum per c.c. Additions of cystine and manganese were made and the cultures kept at $13^{\circ} \mathrm{C}$. in glass vessels resting on a mirror below a skylight in order to increase illumination. Counts were made at intervals with the following result:

January 2, water:

No further addition

No further addition

$+5 \mathrm{mg} . / 1$. cystine

$+2 \mathrm{mg} . / \mathrm{m} \cdot{ }^{3}$ manganese

+ $10 \mathrm{mg} . / \mathrm{m} \cdot{ }^{3}$ manganese

November 29, water:

No further addition

No further addition

$+5 \mathrm{mg}$./ 1 . cystine

+ Io $\mathrm{mg} \cdot / \mathrm{m}^{3}$ manganese

+ ro mg. $/ \mathrm{m}^{3}$ manganese, $0.25 \mathrm{mg}$. $/ 1$. cystine

+ Io mg. $/ \mathrm{m}^{3}$ manganese, I mg. $/ \mathrm{l}$. cystine $a$ denotes presence of auxospores.

\begin{tabular}{|c|c|c|c|c|}
\hline \multicolumn{5}{|c|}{ Cells per c.c. after } \\
\hline$\stackrel{3}{\text { days }}$ & $\stackrel{5}{\text { days }}$ & $\stackrel{9}{\text { days }}$ & $\begin{array}{c}\text { I3 } \\
\text { days }\end{array}$ & $\begin{array}{c}22 \\
\text { days }\end{array}$ \\
\hline 40 & $38 a$ & $d$ & . & $\cdots$ \\
\hline 37 & $26 a$ & $d$ & $\cdots$ & . \\
\hline 62 & 66 & $d$ & $\ldots$ & $\ldots$ \\
\hline 59 & 85 & $223 a$ & $428 a$ & $\ldots$ \\
\hline 62 & 100 & 540 & IIIO & 2420 \\
\hline 43 & $40 a$ & $d$ & . & . \\
\hline 33 & $33 a$ & $d$ & $\ldots$ & $\ldots$ \\
\hline 40 & 35 & $d$ & $\cdots$ & $\cdots$ \\
\hline 72 & 129 & 613 & I560 & I950 \\
\hline 86 & I56 & 860 & 2130 & 2150 \\
\hline 79 & I80 & 920 & 2040 & 2540 \\
\hline
\end{tabular}

$d$ denotes disintegrating cells. 
With the freshly collected January water, adding a considerable dose of cystine prevented auxospore formation but had little effect on growth. Adding manganese, on the other hand, had a marked effect on growth.

With the water collected on November 29, cystine alone had no effect on growth but prevented auxospore formation. In the presence of an ample sufficiency of manganese, the effect of added cystine became apparent even at a concentration of $0.25 \mathrm{mg}$. $/ 1$.

The water collected on January 2 only made a poor growth with the addition of $2 \mathrm{mg}$. Mn $/ \mathrm{m}^{3}$, so an experiment was made to find out whether the effect of small additions of manganese was considerably augmented by small additions of cystine. It showed that the addition of $0.5 \mathrm{mg}$. $\mathrm{Mn} / \mathrm{m} .^{3}$ had little effect and the addition to this of $0.5 \mathrm{mg}$. cystine per litre brought about only a slight further increase. This small quantity of cystine caused only a small increase to the growth brought about by the addition of $2 \mathrm{mg} . \mathrm{Mn} / \mathrm{m} .{ }^{3}$ when added in conjunction with it.

\section{EfFect of Storage on Natural Sea Water}

A quantity of offshore sea water collected in January I938 was filtered and, after enrichment with nitrates, phosphates and iron, found able to support a healthy growth of Ditylum yielding a moderate crop. Unfortunately no counts were made of the final crops these "fertile I937-8 winter waters" would yield-it is assessed as some 2000 cells of mixed diameters per c.c.

After being stored in a glass vessel for several months, it was noticed that this water would no longer support a good growth. By the end of July it would only allow a few cell divisions to take place. The growth was not greatly increased by the addition of cystine, nor was it increased by keeping the culture cool and in a dim light approaching more closely the physical conditions earlier in the year.

The effect of adding an extract of Ulva, from which the "A" active substances had been adsorbed on carbon, was tried. The addition of this alone did not lead to a vigorous growth such as occurred when both this and cystine were added together.

A carboy of open sea water had been collected in December I937 and stored, unfiltered. When this was examined in September, after nine months' storage, it was found to behave in the same way as the water stored after filtration in a flask. After enrichment with nitrates, phosphates, and iron and insemination with the diatoms, these made at most one or two vegetative divisions before forming auxospores, which did not develop. The addition of cystine alone brought about a very slight increase in vegetative growth before auxospore formation set in. The addition of yeast extract which had been freed from "A" by continuous extraction with butyl alcohol had almost no effect. The addition of both cystine and extract caused a healthy and vigorous vegetative growthapproximately I600 cells per c.c. being produced. 


\section{On the Nature of Organic " $N$ " Accessories}

Some information concerning the nature of "A" accessories had been obtained from the experiments with artificial sea water, but virtually no information concerning the " $\mathrm{N}$ " group except that an organic substance or substances were probably a necessary part. The next step was clearly to investigate the " $\mathrm{N}$ " substances lacking in stored sea water. As a preliminary a number of physiologically active compounds, including heteroauxin, vitamins $\mathrm{B}_{2}$ and $\mathrm{C}, \beta$-alanine and nicotinic acid, were tried out for " $\mathrm{N}$ " activity without result. Having arrived at this impasse, the following line of reasoning provided the first clue:

(i) A very active preparation of " $\mathrm{N}$ " had been obtained by continuous extraction of a yeast extract with (aqueous) butyl alcohol, a process which carries over many of the amino acids.

(ii) It had been noticed that a heavy dosage with cystine of artificial sea water would allow a certain but limited amount of growth by the diatom. This suggested that the $-\mathrm{CH}_{2}-\mathrm{CH}\left(\mathrm{NH}_{2}\right) \mathrm{COOH}$ grouping in cystine itself had a small measure of " $\mathrm{N}$ " activity. With this possibility in view the effect of $d l-\alpha$-amino-propionic acid ( $\alpha$-alanine) was tried as a substitute for " $\mathrm{N}$ ".

When added in concentrations between I and $10 \mathrm{mg}$./1. to stored sea water enriched with nitrates, phosphates, iron, cystine and in some cases manganese, it brought about an increased growth of the diatom in twelve experiments, and no increase in one experiment. Moreover, the effect was complementary to that of cystine in the two following experiments:

Sea water collected January, filtered and stored, enriched with $\mathrm{N}, \mathrm{P}, \mathrm{Fe}$ and inseminated with Ditylum September 2 I938. Counts made September 8:

$\begin{array}{lc} & \text { Cells per c.c. } \\ \text { No further addition } & 2 \mathrm{II} \\ \text { Io } \mathrm{mg} \text {./1. cystine } & 6 \mathrm{I} 6 \\ \text { Io } \mathrm{mg} \text {./1. } d \text { - } \alpha \text {-alanine } & 459 \\ \text { Io } \mathrm{mg} \text {./1. cystine + Io mg./1. } \alpha \text {-alanine } & \text { I800 }\end{array}$

Similar procedure; inseminated September 5, counts made September Io:

No further addition
$5 \mathrm{mg} . / 1$. cystine
$5 \mathrm{mg} . / 1 . d l-\alpha$-alanine
$5 \mathrm{mg} . / 1 . d l-\alpha$-alanine $+5 \mathrm{mg} . / 1$. cystine
I mg./1. $d l$ - $\alpha$-alanine $+5 \mathrm{mg} . / 1$. cystine

Cells per c.c.

It is noteworthy that the addition of $\alpha$-alanine alone had little effect. Subsequent experiments suggested the possibility that the activity of $\alpha$-alanine and other organic substances might conceivably be due to traces of impurity, such as manganese, but the relative inactivity of these organic substances when added alone without cystine is opposed to this possibility.

Experiments with this and other substances to find whether their addition caused growth in stored sea water enriched with cystine are summarized in the 
following table, and show that a number of related amino acids do not share the activity of $\alpha$-alanine.

The effect of adding lactate, in which the amino group occurring in $\alpha$ alanine is replaced by a hydroxyl group, was tried and this was found to be active. Its activity is shared by a number of hydroxy compounds as shown in the table. It may be significant that these hydroxy compounds share the property of forming complexes with iron and with manganese, rendering both metals less readily precipitated in alkaline media. Thus gluconic acid forms complexes with the salts of both metals which are not precipitated in $N / 2$ sodium hydroxide.

$d l$ - $\mathrm{CH}_{3} \mathrm{CH}\left(\mathrm{NH}_{2}\right) \mathrm{COOH} d l$ - $\alpha$-alanine $d$ - $\mathrm{CH}_{3} \mathrm{CH}\left(\mathrm{NH}_{2}\right) \mathrm{COOH} d$ - $\alpha$-alanine

$\mathrm{CH}_{2}\left(\mathrm{NH}_{2}\right) \mathrm{CH}_{2} \mathrm{COOH} \beta$-alanine

$\mathrm{CH}_{3} \mathrm{CH}_{2} \mathrm{COOH}$ propionic acid

$d l$ - $\mathrm{CH}_{3} \mathrm{CH}(\mathrm{OH}) \mathrm{COOH} d l$-lactic acid

$\left.\mathrm{CH}_{2} \mathrm{OH}\right) \mathrm{COOH}$ glycollic acid

$\mathrm{CH}_{2}\left(\mathrm{NH}_{2}\right) \mathrm{COOH}$ glycine

$\mathrm{CH}_{3} \mathrm{COCOOH}$ pyruvic acid

$l$ - $\left(\mathrm{CH}_{3}\right)_{2} \cdot \mathrm{CH} . \mathrm{CH}_{2} \cdot \mathrm{CH}\left(\mathrm{NH}_{2}\right) \mathrm{COOH} l$-leucine

$d-\left(\mathrm{CH}_{3}\right)_{2} . \mathrm{CH} \cdot \mathrm{CH}_{2} . \mathrm{CH}\left(\mathrm{NH}_{2}\right) \mathrm{COOH} d$-leucine

$\mathrm{C}_{8} \mathrm{H}_{6} \mathrm{NCH}_{2} \mathrm{CH}\left(\mathrm{NH}_{2}\right) \mathrm{COOH}$-tryptophane

$d l$-proline

$\mathrm{C}_{5} \mathrm{H}_{6}(\mathrm{OH})_{5} \mathrm{COOH}$ gluconic acid

$d-\mathrm{C}_{5} \mathrm{H}_{6}(\mathrm{OH})_{5} \mathrm{CHO}$ dextrose

$l-\mathrm{C}_{5} \mathrm{H}_{6}(\mathrm{OH})_{5} \mathrm{CHO}$ laevulose

$\mathrm{C}_{6} \mathrm{H}_{6}(\mathrm{OH})_{6}$ inosite

\begin{tabular}{|c|c|}
\hline Increased growth & No increased growth \\
\hline In $\mathrm{I} 2$ exp. & In I exp. \\
\hline I, & 3 \\
\hline$\circ$ & $2 \%$ \\
\hline $0 \%$ & $2 \%$ \\
\hline $2 \%$ & 0, \\
\hline & 2, \\
\hline Slight in 2 exp. & I \\
\hline I exp. & I \\
\hline Slight in I exp. & I \\
\hline o exp. & I \\
\hline 0, & $3 \%$ \\
\hline 0 , & 2 \\
\hline $5 \%$ & 3 \\
\hline 9 & Do ," \\
\hline Slight in 3 exp. & $\begin{array}{l}\text { Doubtrul in } \\
\text { I exp. }\end{array}$ \\
\hline
\end{tabular}

In the majority of experiments the quantity added was $2 \mathrm{mg}$. 1. , and in many of the experiments the increased growth took place in the presence of added manganese.

It was noticed that the effect of $\alpha$-alanine appeared less marked as the days became shorter and the diatoms were growing less rapidly. The experiments made in early September with water collected during the previous January were repeated during a period of dull weather starting on November 4 when the samples were inseminated with Ditylum. Counts were made on November 7, 9 and I2, when many cells had disintegrated.

Cells per c.c.

January water enriched N, P, Fe

Ditto $+2 \mathrm{mg} . / 1 . \alpha$-alanine

Ditto +5 mg./1. cystine

Ditto +5 mg./1. cystine $+2 \mathrm{mg}$./1. $\alpha$-alanine

Ditto $+5 \mathrm{mg} . / 1 .+2 \mathrm{mg} . / 1$. dextrose

\begin{tabular}{|c|c|c|}
\hline Nov. 7 & Nov. 9 & Nov. I2 \\
\hline 94 & 66 & 38 \\
\hline I03 & 78 & 39 \\
\hline 207 & 420 & 200 \\
\hline 303 & 545 & 460 \\
\hline IO40 & .. & 1300 \\
\hline
\end{tabular}

This experiment shows the greater " $\mathrm{N}$ " activity of dextrose and bears out the general observation that the effect of $\alpha$-alanine was less during slow growth in dull weather. 


\section{EFFECT OF MANGANESE}

In these experiments with organic compounds possessing $\mathrm{N}$ activity the final growth or crop was not a large one. It was clear that further growth was held back through lack of some further accessory nutrient.

During the course of the earlier work it had been found that growth in artificial sea water was increased by adding $25 \mathrm{mg} . / \mathrm{m} .{ }^{3}$ of $\mathrm{Cu}, \mathrm{Mn}, \mathrm{Co}, \mathrm{Zn}$ and As as salts. The effect of this same mixture of "additional salts" was tried on growth in stored sea water enriched with $\mathrm{N}, \mathrm{P}, \mathrm{Fe}$, cystine and $\alpha$-alanine. It brought about a very markedly increased crop. The following experiment shows that the effect is due, for the most part, to the manganese.

Stored sea water enriched with N, P, Fe, $5 \mathrm{mg}$./1. cystine and I mg./1. $\alpha$-alanine was inseminated with Ditylum in October 5. On October II the following observations were made:

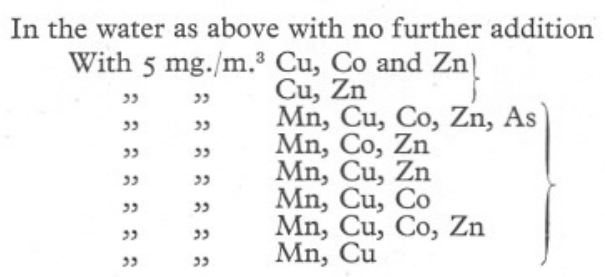

Almost all auxospores
Slight increase about
$50 \%$ auxospores

Heavy growth, no auxospores

It appeared from these and subsequent experiments that a very small supply of manganese promotes continued growth of this Ditylum.

The amount of manganese in samples of ocean and inshore waters from various depths has been estimated by Thompson and Wilson (1935), who found quantities varying between I and Io $\mathrm{mg} . / \mathrm{m}^{3}$

Continued experiments with stored sea water showed that after enrichment with $\mathrm{N}, \mathrm{P}$ and $\mathrm{Fe}$, the addition of $\mathrm{ro}$ to $20 \mathrm{mg}$. $/ \mathrm{m}^{3}$ of manganese would allow a moderate, and sometimes good, growth of Ditylum. Furthermore, offshore water collected on November 4 I938 which after filtering, sterilizing and enrichment with N, P and Fe, allowed no growth of the Ditylum, behaving like stored water, on adding $10 \mathrm{mg} . / \mathrm{m} .^{3}$ of manganese permitted a good growth to take place. Waters collected on November 28 I938, and January 2 I939 behaved in the same manner.

When cystine and one of the "N"-active organic compounds, as gluconic acid or dextrose, was added to the enriched stored sea water in addition to manganese, still further increased crops were obtained. A number of experiments were made, with such additions and it became apparent that growth was finally brought to a standstill through lack of another necessary substance. The water, amply enriched with $\mathrm{N}$ and $\mathrm{P}$ and, as far as one could judge, with $\mathrm{Fe}$, $\mathrm{Mn}$ and organic compounds, having $\mathrm{A}$ and $\mathrm{N}$ activity, would not allow more than some five or six thousand cells per c.c. to develop. When such numbers 
were approached the cells became misshapen and had the general appearance of diatoms lacking silica.

A dilute solution of commercial waterglass was neutralized with hydrochloric acid to give a sol containing ca. $0 . \mathrm{I} \%$ of $\mathrm{SiO}_{2}$. On adding this to provide some $20 \mathrm{mg}$. $\mathrm{SiO}_{2} / 1$. to stored sea water enriched with $\mathrm{N}, \mathrm{P}, \mathrm{Fe}$, $\mathrm{Mn}$, cystine and gluconic acid, a growth exceeding 20,000 cells per c.c. was obtained, turning the medium the colour of pale sherry. It was found that without the cystine and gluconic acid a very considerable growth would take place provided manganese and silica were added. It appeared either that the commercial water glass contained (? organic) accessory substances or that the stored sea water contained sufficient to allow a very heavy growth in the presence of ample $\mathrm{SiO}_{2}$ and $\mathrm{Mn}$. Neutral silica sols were therefore made from the same sample of waterglass after it had been dried and heated to bright redness in a platinum crucible and also from silicon tetrachloride. The growth induced by adding these was less rapid than the growth induced by adding the sol made from (unheated) waterglass, but the final growth in all three cases was similar. A reagent blank containing the sodium hydroxide and hydrochloric acid used in making the sol from silicon tetrachloride was included in the experiment.

Stored sea water enriched with N,P, Fe and $0.02 \mathrm{mg}$. Mn/1., inseminated November 4 . Counts made November I4 and 21 .

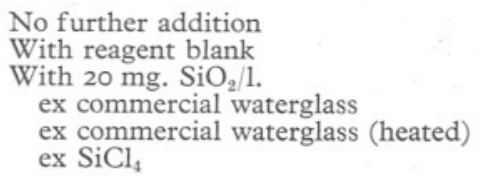

$\begin{array}{cc}\text { Nov. I4 } & \\ \text { cells per c.c. } & \text { Nov. 2I } \\ \text { I2 I0 } & \text { circa } 2700 \\ \text { I240 } & \text { " }, \\ 3440 & \text { circa } \text { I5,000 } \\ \text { I860 } & \text { ", }, \\ \text { 1860 } & \text { ", }\end{array}$

Thus it appears that commercial waterglass contains some substance other than silica which increases the diatoms growth rate, and that this substance is destroyed or rendered inactive by heating to redness.

This and a number of subsequent experiments all showed that the stored natural sea water would support a growth when manganese and silica were added, without any addition of organic accessories other than the citrate added with the iron. The further addition of reasonably small quantities of cystine, I-2 mg./1., led to heavier crops.

Experiments were made to find the quantity of manganese required to allow a continued and vigorous growth of Ditylum in stored sea water in the presence of other accessories added in ample quantity, i.e. silica, cystine, iron and gluconic acid. These indicate that $\mathrm{I}-2 \mathrm{mg} . / \mathrm{m} .^{3}$ of manganese is sufficient, while greater concentrations cause more rapid growth, but not necessarily greater crops. 
Exp. (Dec. 2-9).

No manganese added

$2 \mathrm{mg} . / \mathrm{m}^{3}$ manganese added

$5 \mathrm{mg} . / \mathrm{m}^{3}$ manganese added

Io $\mathrm{mg} . / \mathrm{m} .^{3}$ manganese added

Exp. Dec I4-29.

No manganese added

$0.5 \mathrm{mg} . / \mathrm{m}^{3}$

I. $\mathrm{mg} . / \mathrm{m}^{3}$
Cells per c.c.

\begin{tabular}{|c|c|}
\hline Dec. 6 & Dec. 9 \\
\hline & $\begin{array}{lr}\text { circa } 75 \\
\text { circa } 7000\end{array}$ \\
\hline $\begin{array}{l}2740 \\
3500\end{array}$ & $\begin{array}{l}7000 \\
7000\end{array}$ \\
\hline
\end{tabular}

Cells per c.c.

Dec. 29

175

1400

2000

\section{The EFFect of Other Inorganic Salts}

The experiments with stored sea water had amply shown that it would support a luxuriant growth resulting in an exceptionally heavy crop of the diatom if there were added nitrate, phosphate, silicate, iron as a complex with a polyhydroxy organic compound, manganese and the $-\mathrm{S}-\mathrm{CH}_{2} \mathrm{CH}\left(\mathrm{NH}_{2}\right)$ $\mathrm{COOH}$ group. Later, in I939, it was found that such additions would no longer allow such heavy crops, due, apparently, to the long periods of very dull weather or to a further change in the stored water. Alanine and dextrose when added in addition had little effect in promoting greater crops, although both these substances had a marked effect when added to the same water enriched in the same way, but without added silicate during the previous September and November. Meanwhile, experiments made with artificial sea water had suggested that other elements occurring in minute traces in the water may play some part in the diatoms' metabolism. With this possibility in view the effect of adding such "trace elements" to the stored sea water in addition to iron, manganese and cystine was tried. A preparation containing a representative mixture of such elements likely to play a part in plant metabolism was made by boiling coal ash with hydrochloric acid, evaporating, redissolving and neutralizing to $p \mathrm{H}_{7}$. In three experiments this was found to have a marked effect in increasing the diatoms' growth.

I have great pleasure in acknowledging the many helpful suggestions I have received during the course of this investigation, particularly those from Dr L. H. N. Cooper, Dr W. R. G. Atkins, F.R.S. and Dr E. J. Allen, F.R.S.

\section{SUMMARY}

The diatom Ditylum brightwelli requires, for vigorous growth in artificial sea water, two organic substances, or groups of substances, in addition to inorganic salts.

The substances, or groups, act in a manner complementary to each other. 
The effect of adding either is greatly increased by the presence of the other.

One accessory substance, or group, has been obtained in impure state from natural sea water and from extracts of algae by adsorption on carbon and elution. It has properties of an inorganic acid or internal anhydride. Several organic compounds containing sulphur possess similar activity, including compounds containing the $-\mathrm{S}-\mathrm{CH}_{2}-\mathrm{CH}\left(\mathrm{NH}_{2}\right) \mathrm{COOH}$ group.

The other substance or group has been obtained in impure state from extracts of algae and of yeast. A number of organic compounds have been found to possess similar activity.

The diatom required manganese, a concentration of one part per thousand million being sufficient for vigorous growth.

The diatom made good growth when transferred to natural sea water, enriched with nitrate, phosphate and iron, collected from offshore at intervals between October 1937 and June I938.

The diatom ceased growth and formed auxospores when transferred to natural sea water, enriched in the same manner, collected from offshore during the summer of 1937 and during the period between July I938 and January 1939.

These natural sea waters could be rendered fertile in some cases by adding a compound containing the $-\mathrm{S}-\mathrm{CH}_{2} \mathrm{CH}\left(\mathrm{NH}_{2}\right) \mathrm{COOH}$ group and in some cases by adding $\mathrm{I}-2 \mathrm{mg}$. $\mathrm{Mn} / \mathrm{m}^{3}$

Water collected during the winter of 1938 became infertile after nine months storage, due to loss of available manganese.

\section{REFERENCES}

ALlen, E. J., I9I4. On the culture of the plankton diatom Thalassiosira gravida Cleve in artificial sea water. Fourn. Mar. Biol. Assoc., Vol. x, pp. 4I7-39.

Allen, E. J. \& Nelson, E. W., I9IO. On the artificial culture of marine plankton organisms. Quart. Fourn. Micr. Sci., Vol. 60, pp. 36I-43I.

Gross, F., I937a. Life history of some marine plankton diatoms. Phil. Trans. Roy. Soc., B, Vol. 228, pp. I-47.

Gross, F., I937b. Notes on the culture of some marine plankton organisms. Fourn. Mar. Biol. Assoc., Vol. xxi, pp. 756-68.

HammetT, F. S., I930. The chemical stimulus essential for growth by increase in cell numbers. Protoplasma, Vol. 7, pp. 297-322.

Harvey, H. W., I933. On the rate of diatom growth. Fourn. Mar. Biol. Assoc., Vol. xIX, pp. 253-76.

Harvey, H. W., I937. The supply of iron to diatoms. Fourn. Mar. Biol. Assoc., Vol. XxII, pp. 205-I9.

Keys, A., Christiensen, E. H. \& Krogh, A. The organic metabolism of sea water. fourn. Mar. Biol. Assoc., Vol. xx, pp. 628-46.

KöGL, F. \& FrIEs, N., I937. Ueber den Einfluss von Biotin, Aneurin und Mesoinosit auf das Wachstum verschiedener Pilzarten. Zeit. phys. Chem., Bd. 249, p. 93.

Kögl, F. \& HAAgen-SMit, A. J., 1936. Biotin und Aneurin als Phytohormone. Zeit. physiol. Chem., Vol. 243, p. 209. 
Kögl, F. \& Tonnis, B., I936. Ueber das Bios Problem. Zeit. physiol. Chem., Vol. 242, p. 43.

MAZUR, A. \& Clark, H. T., I938. The amino acids of certain marine algae. Fourn. Biol. Chem., Vol. I23, pp. 729-40.

Peach, E. A. \& Drummond, J. C., I924. On the culture of the marine diatom Nitzschia closterium f. minutissima in artificial sea water. Biochem. Fourn., Vol. I8, pp. 464-8. Pringsheim, E. G., I936. Der Rätsel der Erdabkochung. Bot. Centralblatt, Beiheft $55 a$.

Thompson, T. G. \& Wilson, T. L., I935. The occurrence and determination of manganese in sea water. Fourn. Amer. Chem. Soc., Vol. 57, p. 233. 